九州大学学術情報リポジトリ

Kyushu University Institutional Repository

Bacterial Lysis of Clostridium Species : Effect of Fradiomycin on the Activities of Various Lytic Enzymes Active toward Clostridium saccharoperbutylacetotonicum (Part 5)

Ogata, Seiya

Laboratory of Applied Microbiology, Faculty of Agriculture, Kyushu University

Umeda, Aki io

Laboratory of Applied Microbiology, Faculty of Agriculture, Kyushu University

Hongo, Motoyoshi

Laboratory of Applied Microbiology, Faculty of Agriculture, Kyushu University

https://doi.org/10.5109/22867

出版情報 : 九州大学大学院農学研究院紀要. 19 (1)，pp.49-59，1974-10. Kyushu University バージョン：

権利関係 : 
J. Fac. Agr., Kyushu Univ., 19, 49-59 (1974)

\title{
Bacterial Lysis of Clostridium Species \\ Effect of Fradiomycin on the Activities of Various \\ Lytic Enzymes Active toward Clostridium saccharoperbutylacetonicum (Part 5)
}

\author{
Seiya Ogata, Akiio Umeda and Motoyoshi Hongo \\ Laboratory of Applied Microbiology, Faculty of Agriculture, \\ Kyushu University, Fukuoka
}

(Received July 31, 1974)

\begin{abstract}
Fradiomycin (Neomycin) at above $100 \mu \mathrm{g} / \mathrm{ml}$ drastically stopped the autolysis of Clostridium saccharoperbutylacetonicum, and its other cellular lysis induced by phage HM 2 infection, phage HM 7 infection and a bacteriocin clostocin 0 induction. Similar inhibitory effect of fradiomycin was observed with the cellular lysis induced by penicillin or sodium ion treatment in the co-operation of autolysin. However, phage HM 3 -induced lysis was not inhibited by the addition of fradiomycin. In an in vitro-reaction system, fradiomycin also inhibited the action of isolated autolysin, phage HM 2endolysin, phage HM 7-endolysin and clostocin 0-endolysin upon the formalin-treated organisms or cell wall used as the substrate of C. saccharoperbutylacetonicum, whereas, it did not inhibit the action of isolated phage HM 3-endolysin. Therefore, fradiomycin seemed to be a specific inhibitor against the activities of some lytic enzymes active on C. saccharoperbutylacetonicum.
\end{abstract}

\section{INTRODUCTION}

Growing Clostridium saccharoperbutylacetonicum is lysed by various factors such as phage infection, bacteriocin induction, penicillin treatment or sodium ion treatment. The production of phages (HM 2, HM 3, HM 7 : Hongo and Murata, 1965; Ogata et al., 1969) or inducible bacteriocin (clostocin 0: Ogata et al., 1972) and the release of these particles, are accompanied by the lysis of the producer organisms. The cellular lysis is caused by the cleavage of cell wall by endolysin (endolytic enzyme) synthesized after phage infection or bacteriocin induction. On the other hand, the penicillin-induced lysis (Ogata et al., 1974a) and sodium ion-induced lysis (Ogata and Hongo, $1973 ; 1974)$ are due to the action of autolysin (autolytic enzyme).

In previous paper (Ogata et al., 1974c), we demonstrated that mitomycin Cinduced lysis (Ogata et al., 1972), accompanied with the production of a bacteirocin clostocin 0 , was drastically stopped by the addition of fradiomycin, kanamycin, novobiocin, streptomycin, viomycin, or polymyxin B. Among these 6 antibiotics, fradiomycin showed a much stronger inhibitory effect. Therefore, further studies are necessary to clarify the effect of fradiomycin on lysis inhibition. In this paper, a systematic test using many lytic phenomena described above is undertaken to know whether any specific lysis may be inhibited 
by the treatment with fradiomycin. Furthermore, this paper deals with the effect of fradiomycin on an in vitro-lysis of isolated cell wall or formalin-treated organisms by partially purified lytic enzymes.

\section{MATERIALS AND METHODS}

\section{Organisms}

The strains used were Nl-4 (ATCC 13564) and Nl-504 (ATCC 27022) of Clo. stridium saccharoperbutylacetonicum previously found- to produce an inducible phage tail-like bacteriocin, clostocin 0 (Ogata et al., 1972). Phage HM 2 (ATCC 13564B1) and phage HM 3 (ATCC 13564-B2) were grown on the strain Nl-4, and phage HM 7 (ATCC 27022-B) was grown on the strain Nl-504 (Hongo and Murata, 1965; Ogata et al., 1969).

\section{Medium and cultural condition}

Growth of the bacterial organisms was made at $30^{\circ} \mathrm{C}$ under a reduced atmospheric pressure (5 to $10 \mathrm{~mm} \mathrm{Hg}$ ) in TYA medium (Ogata and Hongo, 1973) which contained (g/l distilled water) : glucose, 40; Bacto-tryptone (Difco), 6; yeast extract (Daigo Eiyo Kagaku Ltd.), 2; ammonium acetate, $3 ; \mathrm{KH}_{2} \mathrm{PO}_{4}, 0.5$; $\mathrm{MgSO}_{4} \cdot 7 \mathrm{H}_{2} \mathrm{O}, 0.4 ; \mathrm{FeSO}_{4} \cdot 7 \mathrm{H}_{2} \mathrm{O}, 0.01$; at $\mathrm{pH}$ 6.5. To obtain a young exponentially growing culture, fresh medium was inoculated with sufficient organisms to produce an initial optical density (OD) of 0.1 at $660 \mathrm{~nm}$ and, unless otherwise mentioned, the culture was incubated until its ${ }^{\circ} D_{66}$ became 0.25 to 0.3 (ca. 8 to $10 \times 10^{7}$ cells $\left./ \mathrm{ml}\right)$.

\section{Turbidity measurement}

Optical density (OD) of the culture, cell and cell wall suspensions, were measured at $660 \mathrm{~nm}$ with a photoelectric colorimeter (Model 7A, Tokyo Koden Ltd., or Type-101, Hitachi Ltd.).

\section{Preparation of phage lysate and phage}

Phage lysate and purified phages were prepared by the procedure as described previously (Hongo and Ogata, 1968 ; Ogata et al., 1969). The phages in $0.005 \mathrm{M}$ Tris- $\mathrm{HCl}$ buffer ( $\mathrm{pH} 7.2$ ) containing $0.005 \mathrm{M} \mathrm{MgSO}_{4}$ and $5 \%(\mathrm{v} / \mathrm{v}$ ) glycerol were stored at $-20^{\circ} \mathrm{C}$ in a deepfreezer until use (Hongo and Ogata, 1968).

\section{Induction of clostocin 0 by mitomycin $\mathbf{C}$ treatment}

Culture grown anaerobically at $30^{\circ} \mathrm{C}$ to $\mathrm{OD}_{660}$ of 0.25 were treated for $15 \mathrm{~min}$ at $30^{\circ} \mathrm{C}$ with $4 \mu \mathrm{g} / \mathrm{ml}$ of mitomycin C (Ogata et al., 1972). Excess mitomycin C was removed by centrifugation at $9,000 \times \mathrm{g}$ for $5 \mathrm{~min}$. The harvested organisms were resuspended in a prewarmed TYA medium to an $\mathrm{OD}_{66_{0}}$ of 0.25 , and the culture was incubated in the usual manner with reading of ${ } D_{660}$ being made at 30- or 60-min intervals.

\section{preparation of cell wall and formalin-treated organisms}

The cell wall of strain Nl-4 or Nl-504 was prepared as described in previous papers (Hongo et al., 1974; Ogata et al., 1974b). The cells were harvested in middle logarithmic growth phase, and suspended in cold distilled water. The crude cell wall was prepared by differential centrifugation, after disruption of 
the cells by sonication for 15 min using insoneter (model $200 \mathrm{M}$, Kubota Ltd.). The resulting cell wall was immediately exposed to $1 \%$ SDS (sodium dodecyl sulfate) solution with stirring at $37^{\circ} \mathrm{C}$ for $15 \mathrm{hr}$. The SDS-treated cell wall was washed at the centrifuge three times with distilled water, and then suspended in $0.067 \mathrm{M}$ phosphate buffer ( $\mathrm{pH}$ '7.0) containing trypsin $(0.5 \mathrm{mg} / \mathrm{ml}$, Sigma 'Chemical Co.). After stirring for $4 \mathrm{hr}$ at $37^{\circ} \mathrm{C}$, the cell wall was sedimented by centrifuging, washed 3 to 5 times with distilled water and finally suspended in a minimum volume of water, and freeze-dried.

Formalin-treated organisms were prepared by exposing the harvested logarithmic phase organisms for $30 \mathrm{~min}$ at room temperature to $0.067 \mathrm{M}$ phosphate buffer ( $\mathrm{pH}$ 6.5) containing $5 \%$ (v/v) formalin. The organisms were washed twice with cold phosphate buffer (without formalin), and suspended in the same buffer. The formalin treatment was performed in order to protect the organisms from autolysis.

\section{Preparation of clostocin 0-endolysin or phage-endolysin}

Partially purified endolysin filtered through Sephadex G-75, was used in this work.

The lysate obtained from mitomycin C-treated or phage-infected organisms was centrifuged at $10,000 x \boldsymbol{g}$ for $10 \mathrm{~min}$ to remove cell debris. The endolysin in the lysate was concentrated by ammonium sulfate precipitation. The resulting enzyme solution was dialyzed against $0.067 \mathrm{M}$ phosphate buffer ( $\mathrm{pH} 6.5$ ), and then centrifuged at $60,000 \mathrm{x}$ g for $60 \mathrm{~min}$ to remove clostocin 0 or phage particles. The supernatant was applied to gel filtration over Sephadex G-75 at $4^{\circ} \mathrm{C}$, and the eluted fraction was concentrated in the collodion bag. By the use of this method, the endolysin was purified about 100-fold. Purification of phage HM 7endolysin had been described in more detail in a previous paper (Hongo et d., 1974). Purification of other endolysins (clostocin 0-, phage HM 2- and phage HM 3-endolysins) will be described in further detail in the future papers.

\section{Preparation of autolysin}

Autolysin was obtained from the culture of young growing organisms, and also applied to ammonium sulfate precipitation and to gel filtration over Sephadex G-75. Purification of autolysin also will be described in the future paper.

\section{Digestion of formalin-treated organisms by purified enzyme}

Sample ( $1 \mathrm{ml}: 1$ to 3 units) and $4 \mathrm{ml}$ of a substrate were suspended in 0.067 $\mathrm{M}$ phosphate buffer ( $\mathrm{pH}$ 6.5) to an initial $\mathrm{OD}_{66}$ of 0.50 . The mixture was incubated at $30^{\circ} \mathrm{C}$. Units were calculated from the following equation : units $=1,000$ $\times \Delta \mathrm{OD} / \mathrm{min}$. A control tube contained the endolysin boiled for $5 \mathrm{~min}$.

\section{Digestion of cell wall by purified enzyme}

Sample ( $0.1 \mathrm{ml}: 1$ to 3 units) and $0.4 \mathrm{ml}$ of a substrate were suspended in $0.067 \mathrm{M}$ phosphate buffer to an initial $\mathrm{OD}_{660}$ of 0.50 . In this experiment, optimum pH for the lytic enzyme activity was used: $\mathrm{pH} 5.0$ buffer was used for clostocin O-endolysin, phage HM 2-endolysin and autolysin ; pH 6.5 buffer was used for phage HM 3-endolysin and phage HM 7-endolysin. Other experimental conditions and unit calculation were the same as described above. 


\section{RESULTS}

\section{Effect of fradiomycin on mitomycin C-induced lysis}

Mitomycin C-induced lysis, which was accompanied with the production of clostocin 0 , began at about $3 \mathrm{hr}$ after mitomycin $\mathrm{C}$ treatment, and completed some $5 \mathrm{hr}$ or more later, as shown in Fig. 1. Cellular lysis was produced by the cleavage of cell wall by clostocin 0-endolysin, whose synthesis finished at about $2.5 \mathrm{hr}$ after mitomycin C treatment (Ogata and Hongo, 1974).

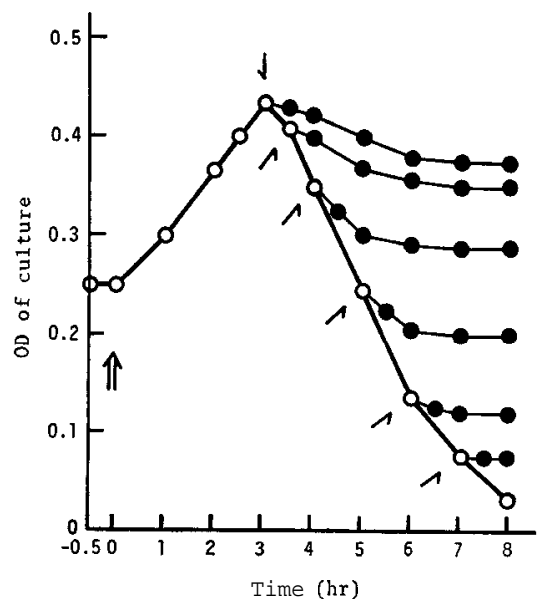

Fig. 1. Effect of fradiomycin added at various periods on mitomycin C-induced lysis.

0 No fradiomycin, - Fradiomycin treatment $(100 \mu \mathrm{g} / \mathrm{ml})$.

After mitomycin $\mathrm{C}$ treatment, organisms harvested by centrifugation were resuspended in a fresh medium prewarmed to $30^{\circ} \mathrm{C}$ at the period indicated by a double arrow, and the incubation was continued at $30^{\circ} \mathrm{C}$. Aliquots of a culture were withdrawn at various periods indicated by the arrows to measure the effect of fradiomycin on the mitomycin C-induced lysis. After the addition of fradiomycin, $\mathrm{OD}_{660}$ was followed for 1 to $5 \mathrm{hr}$ at $30^{\circ} \mathrm{C}$. Fig. 1 shows that fradiomycin at $100 \mu \mathrm{g} / \mathrm{ml}$ almost completely stopped cellular lysis whenever it was added during the lytic process.

\section{Effect of fradiomycin on phage HM 2-induced lysis}

Experiments were then performed to see the effect of fradiomycin on phage HM 2-induced lysis. The culture was added with phage HM 2 at the multiplicity of 10 . After incubation for $5 \mathrm{~min}$ at $30^{\circ} \mathrm{C}$, unadsorbed phages were removed by centrifuging at $9,000 \mathrm{xg}$ for $5 \mathrm{~min}$. The harvested organisms were resuspended in a fresh medium prewarmed to $30^{\circ} \mathrm{C}$ at the period indicated by a double arrow, and the incubation was continued at $30^{\circ} \mathrm{C}$. Fradiomycin was added at the various periods indicated by the arrows, as shown in Fig. 2. Fradiomycin was also effective in rapidly stopping the phage HM 2-induced lysis whenever it was added during the lytic process. 


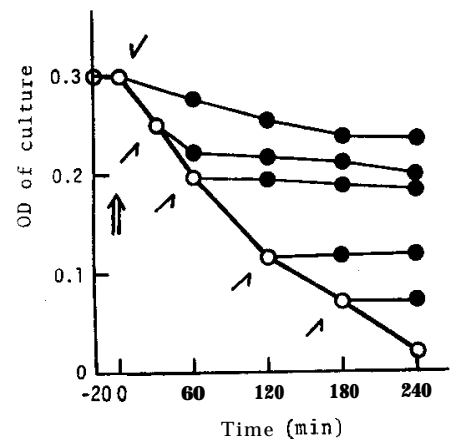

Fig. 2. Effect of fradiomycin added at various periods on the lysis of phage HM 2infected organisms. 0 No fradiomycin, - Fradiomycin treatment $(100 \mu \mathrm{g} / \mathrm{ml})$.

\section{Effect of fradiomycin on phage HM 7-induced lysis}

Similar experiments using phage HM 7 were performed. As shown in Fig. 3 , phage HM 7-induced lysis was also inhibited by fradiomycin, but drastic inhibition was not obtained.

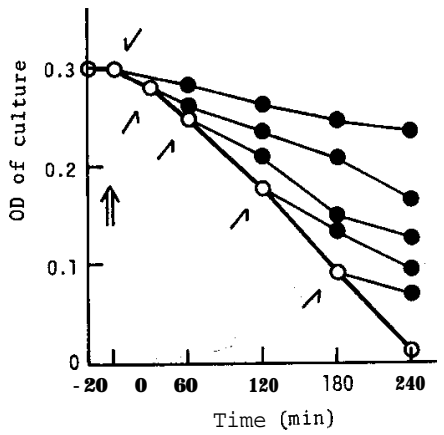

Fig. 3. Effect of fradiomycin added at various periods on the lysis of phage HM 7infected organisms. Experimental conditions and symbols are the same as described in Fig. 2.

\section{Effect of fradiomycin on phage HM 3-induced lysis}

Similar experiments using phage HM 3 were performed as shown in Fig. 4. Phage HM 3-infected organisms were lysed in the presence of fradiomycin through the infection process. However, during early part of the infection process, they became temporarily delayed lytic response. The temporal resistance to lysis of phage-infected organisms could be explained on the inhibition of synthesis of phage and its endolysin by antibiotic treatment (Hongo and Murata, 1967 ; Hongo et al., 1967).

This result indicates that fradiomycin evidently did not inhibit the cellular lysis induced by phage HM 3 infection.

\section{Effect of fradiomycin on penicillin-induced lysis}

It is well known that penicillin inhibits the synthesis of cell wall peptidogly* 


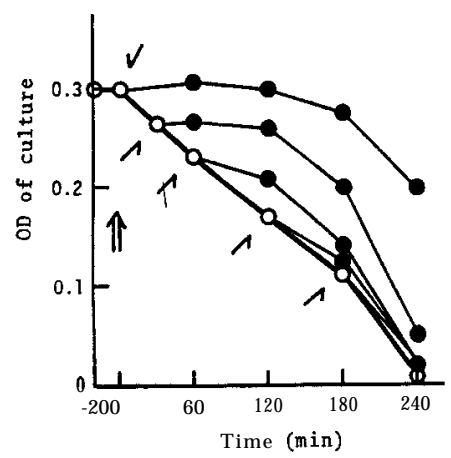

Fig. 4. Effect of fradiomycin added at various periods on the lysis of phage HM 3infected organisms. Experimental conditions and symbols are the same as described in Fig. 2.

can, and bacterial organisms are lysed by penicillin in the presence of autolysin (Higashi and Suginaka, 1972).

The normal growing organisms of C. sacckaroperbutylacetonicum was lysed by penicillin treatment after 60 min-lag period as shown in Fig. 5. To know whether penicillin-induced lysis would be affected by fradiomycin, it was added at intervals to penicillin-treated organisms. As shown in Fig. 5, fradiomycin almost completely stopped the cellular lysis induced by penicillin treatment.

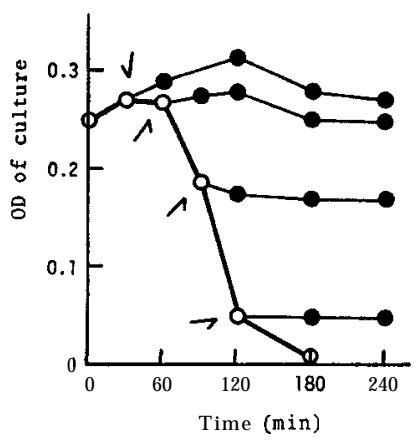

Fig. 5. Effect of fradiomycin added at various periods on penicillin-induced lysis. 0 No fradiomycin, - Fradiomycin treatment $(100 \mu \mathrm{g} / \mathrm{ml})$. Penicillin $\mathrm{G}(100 \mu \mathrm{g} / \mathrm{ml})$.

\section{Effect of fradiomycin on sodium ion-induced lysis}

Growing organisms of C. sacckaroperbutylacetonicum is lysed by the addition of sodium ion $\left(\mathrm{Na}^{+}\right)$at concentrations above $0.1 \mathrm{M}$, this ion having maximum effect at 0.3 M (Ogata and Hongo, 1973). The sodium ion-induced lysis is due to the action of autolysin (Ogata and Hongo, 1974).

The cellular lysis occurred at about 5 min after the addition of $\mathrm{Na}^{+}$and completed at $20 \mathrm{~min}$ or more, as shown in Fig. 6. A larger concentration of fradiomycin was necessary for its inhibitory effect on $\mathrm{Na}^{+}$-induced lysis than on phage-induced lysis, mitomycin C-induced lysis or penicillin-induced lysis, because 


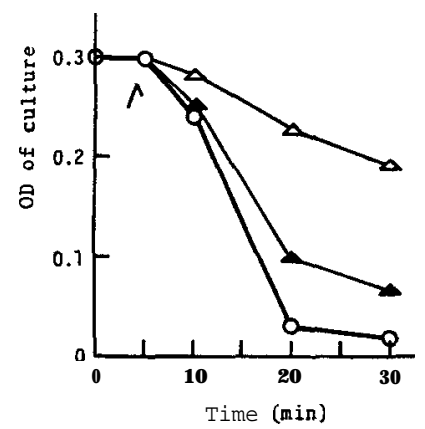

Fig. 6. Effect of fradiomycin on sodium ion-induced lysis. 0 No fradiomycin, A $100 \mu \mathrm{g} / \mathrm{ml}$ fradiomycin, $\triangle 500 \mu \mathrm{g} / \mathrm{ml}$ fradiomycin. Sodium chloride: $0.3 \mathrm{M}$.

the rate of $\mathrm{Na}$-induced lysis was the greatest among these 4 lytic phenomena.

Effect of fradiomycin on whole cell-lytic activities of various endolysins

It might be assumed that the inhibition of cellular lysis by fradiomycin was not due to the result of metabolic perturbation of the organisms. Therefore, the effect of fradiomycin on the lytic activities of partially purified endolysins was examined using formalin-treated organisms of C. saccharoperbutylacetonicum. Clostocin 0-endolysin, phage HM 7-endolysin and phage HM 3-endolysin completely digested the whole cells, whereas phage HM 2-endolysin and autolysin did not.

Fig. 7 shows the effect of fradiomycin on whole cell-lytic activity of clostocin 0-endolysin. The formalin-treated organisms were rapidly lysed when incubated with the endolysin, but, by the addition of fradiomycin at $100 @ \mathrm{~g} / \mathrm{ml}$, lysis of the whole cell suspension was markedly inhibited. The slight lysis of control suspension (with heated endolysin) was due to surviving autolysin. The autolysis was also inhibited by fradiomycin.

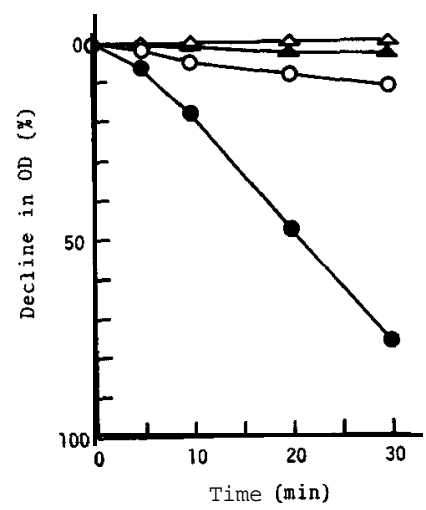

Fig. 7. Effect of fradiomycin on whole cell-lytic activity of clostocin 0-endolysin. 0 Whole cells theated endolysin (control), Whole cells + endolysin, A Whole cells +endolysin $+100 \mu \mathrm{g} / \mathrm{ml}$ fradiomycin. A Whole cellstendolysin $+500 \mu \mathrm{g} / \mathrm{ml}$ fradiomycin. Formalin-treated organisms were used for whole cells. Incubation was performed at $30^{\circ} \mathrm{C}$. Initial $\mathrm{OD}_{660}$ of suspensions were 0.50 . 
Similar experiments were performed with phage HM 7-endolysin and phage HM 3-endolysin. The whole cell-lytic activities of phage HM 7-endolysin but not phage HM 3-endolysin were inhibited, as shown in Figs. 8 and 9.

These results indicate that fradiomycin inhibits the action of isolated clostocin 0-endolysin and phage HM 7-endolysin upon the formalin-treated organisms as the substrate.

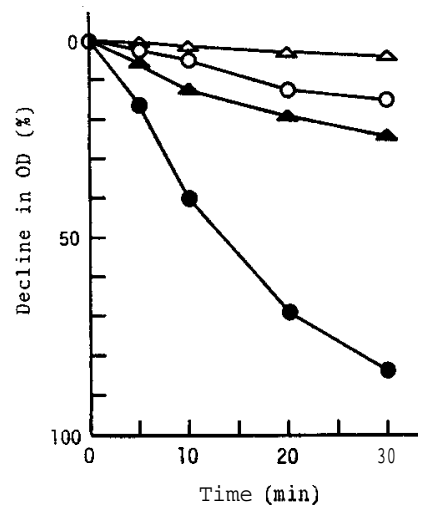

Fig. 8. Effect of fradiomycin on whole cell-lytic activity of phage HM 7-endolysin. Experimental conditions and symbols are the same as described in Fig. 7.

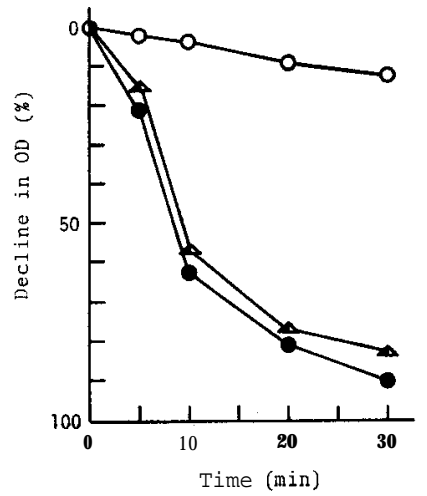

Fig. 9. Effect of fradiomycin on whole cell-lytic activity of phage HM 3-endolysin. Experimental conditions and symbols are the same as described in Fig. 7.

Effect of fradiomycin on cell wall-lytic activities of various endolysins and autoly$\sin$

Similar experiments were performed with isolated cell wall of C. saccharoperbutylacetonicum. Clostocin 0-endolysin, phage HM 2-endolysin and autolysin possessed two enzymatic actions; one was $\mathrm{N}$-acetylmuramidase activity, and the other cleaved the bond between peptidoglycan and D-alanine of teichoic acid-like substance. These three enzymes should not be looked as the same ; many of their 
properties were different from one another (preparing for publication). Phage HM 7-endolysin and phage HM 3-endolysin had the activities of $\mathrm{N}$-acetylmuramyl-L-alanine amidase (Hongo et al., 1974; Ogata $e t$ al., 1974b) and of N-acetylmuramidase (Tahara et al., 1974), respectively.

The cell wall-lytic activities of clostocin 0-endolysin, phage HM 2-endolysin, and autolysin was apparently inhibited by fradiomycin, whereas, a larger concentration of fradiomycin was necessary for its inhibitory effect on cell wall digestion than on the lysis of whole cells (Table 1 and Figs. 7 to 9). Digestion of the cell wall by enzymes was not inhibited by $100 \mu \mathrm{g} / \mathrm{ml}$ of fradiomycin, in contrast to the whole cells. Complete inhibition was not obtained even with 1,000 $\mu \mathrm{g} / \mathrm{ml}$ of fradiomycin.

Table 1. Effect of fradiomycin on cell wall-typic activities of various lytic enzymes

\begin{tabular}{rccccc}
\hline $\begin{array}{c}\text { Fradiomycin } \\
\mu \mathrm{g} / \mathrm{ml}\end{array}$ & $\begin{array}{c}\text { Clostocin 0 } \\
\text { endolysin } \\
\%\end{array}$ & $\begin{array}{c}\text { Phage HM 2 } \\
\text { endolysin } \\
\%\end{array}$ & $\begin{array}{c}\text { Phage HM 7 } \\
\text { endolysin } \\
\%\end{array}$ & $\begin{array}{c}\text { Phage HM 3 } \\
\text { endolysin } \\
\%\end{array}$ & $\begin{array}{c}\text { Autolysin } \\
\%\end{array}$ \\
\hline $\mathbf{0}$ & 100 & 100 & 100 & 100 & 100 \\
100 & 97 & 86 & 96 & 100 & 95 \\
500 & 75 & 50 & 92 & 100 & 70 \\
1000 & 30 & 35 & 92 & 100 & 30 \\
\hline
\end{tabular}

The rate of cell wall-digestion in the case of no fradiomycin is expressed as $100 \%$. Incubation was performed for $30 \mathrm{~min}$ at $30^{\circ} \mathrm{C}$.

\section{DISCUSSION}

Fradiomycin had a markedly inhibitory effect upon the lytic action of phage HM 2-endolysin, phage HM 7-endolysin, clostocin 0-endolysin, and autolysin. It responded more strongly to phage HM 2-endolysin, clostocin 0 -endolysin and autolysin than phage HM 7-endolysin. On the other hand, the action of phage HM 3-endolysin was not inhibited even by its concentration of more than 1,000 $\mu \mathrm{g} / \mathrm{ml}$. These different responses seem to be due to the properties of lytic enzymes which will be reported in more detail in some future papers. On the basis of the above evidences, we confirm that fradiomycin is a specific inhibitor against the activities of some lytic enzymes.

A larger concentration of fradiomycin was necessary for its inhibitory effect on the lysis of isolated cell wall than on that of whole cells; in the case of phage HM 7-endolysin, more typical pattern was observed. No explanation has yet been found as to the different behavior of fradiomycin on the cell wall and the cell suspension. Similar observations had been reported in an inhibitory effect of ristocetin A upon the lysis of isolated cell wall and whole organisms by a phageinduced lysin of Streptococcus pyogenes (Doughty and Hayashi, 1962). We have concluded that the lysis of whole organisms is a multistep process.

Role of fradiomycin in the lysis inhibition could not be explained by the formal action of antibiotic, though it is known to be a powerful inhibitor of protein synthesis. Kanamycin, novobiocin, streptomycin, viomycin and polymyxin B also showed a inhibitory effect on the above lytic enzymes. These antibiotics are basic 
antibiotics. In particular, the structural units of fradiomycin, kanamycin, novobiocin and streptomycin are aminosugars resembling glucosamine and muramic acid in the cell wall. It may be assumed that these antibiotics easily combine with lytic enzymes or the cell surface. Therefore, we should pay more attention on the structural properties of these antibiotics. Further studies are now in progress to explore the mode of action of antibiotics on the lytic inhibition.

\section{ACKNOWLEDGEMENTS}

The authors thank Mr. Y. Tahara for his technical assistance in part of this work which was partly supported by a Grant-in-Aid for Scientific Research from the Ministry of Education.

\section{REFFERENCES}

Doughty, C. C. and J. A. Hayashi 1962 Enzymatic properties of a phage-induced lysin affecting group a streptococci. J.Bacteriol., $83: 1058-1068$

Higashi, Y. and H. Suginaka 1972 Role of bacterial membrane components in cell wall biosynthesis. Protein, Nucleic acid and Enzyme $17: 46-56$

Hongo, M. and A. Murata 1965 Some characteristics of the twelve phages obtained from the abnormally fermented broths : Bacteriophages of Clostridium saccharoperbutylacetonicum (part 1). Agr. Biol. Chem., 29: 1135-1139

Hongo, M. and A. Murata 1967 Inhibition of HM-phages by antibiotics : Bacteriophages of Clostridium saccharoperbutylacetonicum (part 8). Agr. Biol. Chem., 31 : 64-72

Hongo, M., A. Murata and K. Kono 1972 Inhibition of HM-phages by kanamycin : Bacteriophages of Clostridium saccharoperbutylacetonicum (part 9). J. Ferment. Technol. (Japan), $45: 461-468$

Hongo, M. and S. Ogata 1968 Inactivation of free HM 2 phage by Deoxyribonuclease: Bacteriophages of Clostridium saccharoperbutylacetonicum (part. 11). Agr. Biol. Chem., 32 : 459-466

Hongo, M., Y. Tahara and S. Ogata 1974 Purification and properties of phage HM 7-induced lytic enzyme of Clostridium saccharoperbutylacetonicum : Lytic enzymes active on Clostridium species (part 1). Agr. Biol. Chem., 38 : 755-761

Ogata, S., K. Choi, Y. Ikeda and M. Hongo 1974a Properties of premature lysis provoked by antibiotics in mitomycin C-induced lysis of Clostridium saccharoperbutylacetonicum : Bacterial lysis of Clostridium species (part 3). J. Gen. Appl. Microbiol., 20: 153-168

Ogata, S. and M. Hongo 1973 Lysis of Clostridium species by univalent cation: Bacterial lysis of Clostridium species (part 1). J. Gen. Appl. Microbiol., 19: 251-261

Ogata, S and M. Hongo 1974 Cell lysis induced by sodium ion and its relation to lytic enzyme systems in Clostridium saccharoperbutylacetonicum : Bacterial lysis of Clostridium species (part 2). J. Gen. Microbiol., $81: 315-323$

Ogata, S., 0. Mihara, Y. Ikeda and M. Hongo 1972 Inducible phage tail-like particles of Clostridium saccharoperbutylacetonicum : Bacteriocins of nonpathogenic Clostridium species (part 3). Agr. Biol. Chem., 36 : 1413-1421

Ogata, S., N. Nagao, Z. Hidaka and M. Hongo 1969 The structure of phage HM 2: Bacteriophages of Clostridium saccharoperbutylacetonicum (part 17). Agr. Biol. Chem., 33 : $1541-$ 1552

Ogata, S., Y. Tahara and M. Hongo 1974b Mode of action of Clostridium phage HM 7-induced lytic enzyme on Clostridium saccharoperbutylacetonicum cell wall peptidoglycan : Lytic enzymes active on Clostridium species (part 2). Agr. Biol. Chem., 38: 763-768 
Ogata, S., A. Umeda and M. Hongo 1974c Fradiomycin and some other antibiotics are specific inhibitors against the endolysin of an inducible bacteriocin : Bacterial lysis of Clostridium species (part 4). J. Gen. Appl.Microbiol., 20: 169-177

Tahara, Y., S. Ogata and M. Hongo 1974 Properties of phage HM S-induced lytic enzyme of Clostridium saccharoperbutylacetonicum : Lytic enzymes active on Clostridium species (part 3). J. Agr. Chem. Soc. (Japan), (in preparation) 